Dr BOŽICA SLAVKOVIĆ MIRIĆ, naučni saradnik

Institut za noviju istoriju Srbije

Beograd, Republika Srbija

bozica.slavkovic@gmail.com

originalan naučni rad

UDK: 327:339.92(497.1:496.5)"1945/1948"

primljeno: 29. maj 2019.

347.235(497.1:496.5)"1945/1948"

prihvaćeno: 20. novembar 2019.

https://doi.org/10.29362/ist20veka.2020.1.sla.107-128

\title{
POGRANIČNI PROMET JUGOSLAVIJE I ALBANIJE I DVOVLASNIČKA IMANJA 1945-1948*
}

APSTRAKT: Na osnovu arhivske građe i stručne literature rad analizira pogranični promet $i$ problem dvovlasničkih imanja Jugoslavije i Albanije tokom 1945-1948. Ove dve države uspostavile su intenzivnu ekonomsku saradnju nakon Drugog svetskog rata. Kao bitno pitanje istaknuto je rešavanje odnosa duž jugoslovensko-albanske granice. Potpisan je Sporazum o pograničnom prometu 1945, a nakon posete Envera Hodže Jugoslaviji sredinom 1946. ukinuta je carinska granica i izjednačene su valute. Probleme oko dvovlasničkih imanja rešavala je mešovita albansko-jugoslovenska komisija. Ipak, svi započeti projekti i rešavana pitanja bili su prekinuti albanskim prihvatanjem Rezolucije Informbiroa u junu 1948, nakon čega je jugoslovensko-albanska granica bila zatvorena.

KLJUČNE REČI: Jugoslavija, Albanija, dvovlasnička imanja, pogranični promet, period posle Drugog svetskog rata

\section{Uvod}

Jugoslavija i Albanija, kao susedne zemlje, bile su upućene jedna na drugu radi uspostavljanja saradnje. Ipak, Jugoslavija je bila obazriva u realizovanju političkih, ekonomskih i kulturnih odnosa sa albanskim susedom, jer su u Albaniji preovladavali patrijarhalni režim, običajno pravo, plemenski nemiri, anarhija, strani uticaj koji je nekritički prihvatan, nebezbednost, kačačka tradicija, slabi putevi, primitivan transport. Postojali su, uz to, i politički konflikti oko razgraničenja. ${ }^{1}$ Ipak, pogranične oblasti poput Skoplja, Bitolja, Ohrida, Struge, Resena, Debra, Prilepa, Peći, Prizrena, Đakovice, Podgorice bile su uzajamno ekonomski zavisne od pograničnih oblasti u Albaniji. ${ }^{2}$

\footnotetext{
* Članak je deo projekta Tranzicija i transformacija - istorijsko nasleđe i identitet Srbije u 20. $v e k u,(47019)$, koji finansira Ministarstvo prosvete, nauke i tehnologije Republike Srbije.

${ }^{1} \mathrm{O}$ razgraničenju i albanskoj graničnoj komisiji videti dokumenta u: Albania and Kosovo. Political and ethnic boundaries 1867-1946, editor Beytullah Destani (Slough: Archive Editions, 1999).

${ }^{2}$ Ljubodrag Dimić i Miladin Milošević, „Međudržavni ugovori između Jugoslavije i Albanije 1918-1939“, Tokovi istorije, br. 1, (1990), 39.
} 
U periodu između dva svetska rata trgovinske veze Jugoslavije i Albanije zavisile su od vojne i političke situacije, pa su bile promenljive. Ipak, ekonomski odnosi sa Albanijom razvijani su u skladu sa Zakonom o izvozu i izvoznim carinama od 23. septembra 1921. i Zakonom o opštoj zakonskoj tarifi. U Albaniju je Kraljevina SHS izvozila žito i robu za ishranu sa mlinarskim proizvodima i prerađevinama od mesa, mineralna ulja, voštanu robu, sapun, organska jedinjenja i boje, pamuk i pamučne tkanine, lan, kudelju, vlakna za predivo, užariju, šivenu robu, prerađevine od kože, pletarske proizvode, artikle od drveta, pečenu zemlju, staklo, gvozdenu robu, alkohol, hemijske i apotekarske proizvode, hartiju, četkarske proizvode i drugo. Uvoz je bio neznatan i odnosio se samo na potrebe užeg pograničnog pojasa.

Kada je Ahmet beg Zogu ${ }^{4}$ došao na vlast, Jugoslavija i Albanija su uspostavile bolje ekonomske odnose. ${ }^{5}$ Izrađen je nacrt ekonomskog ugovora u januaru 1926, koji je zaključen u Beogradu 22. juna 1926, u Skupštini ozakonjen 20. aprila 1929, a konačno ratifikovan 17. maja 1929. ${ }^{6}$ Ovaj Ugovor o trgovini i plovidbi potpisali su dr Momčilo Ninčić, jugoslovenski ministar inostranih poslova, Milto Tutulani, bivši ministar pravde i Džafer Vila, generalni sekretar Ministarstva inostranih poslova Albanije. Trebalo je da važi tri godine i imao je polugodišnji otkazni rok. Regulisao je promet duž granice: olakšice za dolazak stanovništva na pijacu, trgove, stočne sajmove, vašare, odredbe o slanju robe na neizvesnu prodaju, o izgonima stoke na ispašu i zimovanje, o liberalnom postupku pri prometu namirnica i osnovnih potreba u zoni granice. Predviđao je i slobodu trgovine i plovidbe, slobodu putovanja i kretanja, slobodu nastanjivanja, pravnu zaštitu i drugo. Jugoslavija i Albanija su se obavezale da ne ometaju uzajamnu trgovinu bilo kakvim zabranama ili ograničenjima, osim u vanrednim okolnostima. Ovim ugovorom obuhvaćen je i železnički saobraćaj, iako Albanija nije imala železnicu. Mnoge odredbe su kasnije mogle da se sprovedu, uz uvođenje posebnih konvencija (o pošti, o dvovlasnicima, veterinarska konvencija, konvencija za suzbijanje krijumčarenja) i zaključenja sporazuma

\footnotetext{
${ }^{3}$ Isto, 40.

${ }^{4}$ Ahmed beg Zogu (1895-1961), na vlasti u Albaniji od 1922. do 1939. Bio je premijer Albanije 1922-1924, predsednik 1925-1928, prvi i jedini kralj (1928-1939). Više u: Bernd Jurgen Fischer, King Zog and the Struggle for Stability in Albania (Boulder: East European Monographs, 1984); Jason Hunter Tomes, King Zog, Self-Made Monarch of Albania (New York: New York University Press, 2003); Душан Батаковић, „Ахмед бег Зогу и Србија“, у: Научни скуn Србија 1916, приредио Славенко Терзић (Београд: Историјски институт САНУ, 1987), 165-177; Owen Pearson, Albania and King Zog: independence, republic and monarchy 19081939 (London; New York: Centre for Albanian Studies in association with IB Tauris Publishers, 2004); Marenglen Verli, Shqipëria dhe Kosova - historia e një aspirate (Albania and Kosovo story of an aspiration), vol. I-II (Tirana: Botimpex, 2007).

${ }^{5}$ Ђорђе Борозан, Велика Албанија: поријекло - идеје - пракса (Београд: Војноисторијски институт Војске Југославије, 1995), 93-94.

6 Ђорђе Борозан, „Југославија и Албанија у двадесетом вијеку“, Југословенска држава 19181998, приредио Ђорђе О. Пиљевић (Београд: Култура, 1999), 207; Јелена Рафаиловић, Развој индустрије на Балкану. Текстилна индустрија у Краљевини Срба, Хрвата и Словенаца и Бугарској 1919-1929 (Београд: Институт за новију историју Србије, 2018), 224.
} 
(antropoti na albanskoj teritoriji za smeštaj jugoslovenske robe, plovidba na zajedničkim rekama i jezerima, dopunjavanje ugovora novim sporazumima i aranžmanima, eksploatacija i zaštita ribolova u zajedničkim vodama, zajednički sporazum carinskih vlasti o ispaši i zimovanju stoke i drugo). Odredbama o pograničnom prometu bilo je određeno da albansko pogranično stanovništvo sve svoje poljoprivredne, voćarske, stočarske, šumarske, rudarske proizvode, proizvode lova i kućevne izrade može slobodno da prodaje bez carina, taksi ili drugih dažbina. ${ }^{7}$

Da bi se ispoštovao Ugovor, koji je značio uređenje pograničnih zona između jugoslovenske i albanske države, obrazovana je jugoslovensko-albanska komisija. Trebalo je da trgovinski režim u pograničnim delovima postane što slobodniji i sa što manje formalnosti. Takođe, bilo je potrebno obezbediti ličnu sigurnost trgovaca što je u stvari značilo rešavanje političkih problema. ${ }^{8}$ Zatim, pri Jugoslovenskom poslanstvu u Tirani osnovana je Trgovinsko-ekonomska sekcija čiji je zadatak bio da prikuplja podatke o artiklima koje je Albanija uvozila, da obaveštava privrednike i trgovačke kuće o cenama proizvoda i količinama njihove potražnje i potrošnje i o svemu ostalom što je imalo za cilj da se organizuje privredni nastup u Albaniji. ${ }^{9}$ Pored želje i pokušaja da se uspostavi ekonomska saradnja, izvoz je otežavao nedostatak modernih saobraćajnih sredstava i pruge koja bi jugoslovenske ekonomske centre vezivala za Albaniju. ${ }^{10}$

Trgovinski odnosi Jugoslavije i Albanije naročito su počeli da se razvijaju kada je Albanija promenila svoju politiku prema Italiji, sa kojom je imala političke i ekonomske veze. ${ }^{11}$ Potpisani su sporazumi: Dopunski sporazum uz Ugovor o trgovini i plovidbi između Kraljevine Jugoslavije i Kraljevine Albanije potpisan u Beogradu 22. juna 1926. i Zaključni (tajni) protokol od 20. decembra 1933; Dopunski sporazum o pograničnom prometu sa Skadrom od 5. maja 1934. i Sporazum o otkupu ribe iz albanskog dela Skadarskog jezera od 8. maja 1934. ${ }^{12}$ Prema sporazumu o skadarskom tržištu, stanovnici pojedinih sela

${ }^{7}$ Lj. Dimić, M. Milošević, n. d., 42.

${ }^{8}$ Време, 7. 10. 1929; Трговински гласник, 4. 9. 1929; Политика, 1. 8. 1929.

${ }^{9}$ Lj. Dimić, M. Milošević, $n$. d., 43.

10 Jugoslovenski uvoz u Albaniju do 1934. dostigao je 16 miliona zlatnih franaka, dok je albanski izvoz za Jugoslaviju bio 1.755.000 franaka. Prosečno, uvoz robe iz Jugoslavije u Albaniju bio je 7,3\%, a izvoz albanskih produkata u Jugoslaviju dostizao je samo 1,9\% (Правда, 5. 5. 1934). U toku prve godine albansko-jugoslovenske ekonomske saradnje uvoz Kraljevine Jugoslavije bio je tri puta veći nego izvoz iz nje. Uvezeno je robe za 3.205.508 dinara. Celokupan albanski izvoz u 1933. iznosio je 5,74 miliona zlatnih franaka. Lj. Dimić, M. Milošević, n. d., 45.

${ }^{11}$ Божица Славковић Мирић, Политичке, економске и културне прилике на Косову и Метохији 1929-1941 (Београд: Просвета, Принцип, 2018), 135. Od kraja 1932. odnosi Italije i Albanije bili su zaoštreni. Ahmet Zogu je očekivao da će Kraljevina Jugoslavija kompenzovati finansijske teškoće nastale zbog nesporazuma sa Italijom, na osnovu čega bi Albanija preko Balkanskog sporazuma ušla u sistem balkanskih država. Zato je albanski poslanik posetio kralja Aleksandra I 1933, tražeći finansijsku pomoć za Albaniju, ali je kralj odgovorio da Jugoslavija u tom trenutku nema mogućnosti za zajam. Britanci o Kraljevini Jugoslaviji. Godišnji izveštaji Britanskog poslanstva u Beogradu 1921-1938, knj. 2, priredio Živko Avramovski (Beograd: Arhiv Jugoslavije; Zagreb: Globus, 1986), 158-159.

${ }^{12} \mathrm{Lj}$. Dimić, M. Milošević, $n$. d., 43. 
jugoslovenske pogranične zone imali su povlastice da se služe skadarskom pijacom, a isto tako i albanskom stanovništvu pogranične zone bilo je dozvoljeno da se služi jugoslovenskim pijacama u pograničnoj zoni. ${ }^{13}$ U februaru 1934. stupio je na snagu protokol kojim je utvrđena slobodna albansko-jugoslovenska pogranična zona. ${ }^{14} \mathrm{U}$ decembru iste godine Albanija je potpisala sa Jugoslavijom trgovinski ugovor po kojem se susedna država obavezivala da kupuje albanske proizvode u prosečnoj vrednosti albanskog uvoza iz Jugoslavije od 1929. (2.600.000 franaka). ${ }^{15}$ Takođe, radi unapređenja trgovinskih odnosa u Tirani je otvorena filijala Izvozne banke iz Beograda. ${ }^{16}$

Jugoslovensko-albanska granica bila je duga oko $500 \mathrm{~km}$, a granična zona koja bi se koristila olakšicama zalazila je $15 \mathrm{~km}$ u albansku teritoriju, što je podrazumevalo slobodno obrađivanje imanja kao i teranje stoke na ispašu. Albanija je zatražila da se otvori put njenim produktima i da se omogući njihova prodaja u Jugoslaviji. ${ }^{17}$ Trgovinskim protokolom Jugoslavije i Albanije određene su granice albanskih i jugoslovenskih pograničnih zona, rejonski sektori, mesta, putevi, prolazne tačke i tržišta u jugoslovenskoj pograničnoj zoni na koja bi albanski pogranični privrednici donosili svoje proizvode radi prodaje i snabdevanja. Promet sa Albanijom vršio se preko carinarnica u Prizrenu, Ohridu, Struzi, Debru i Bitolju. ${ }^{18}$

Početkom februara 1935. otvoren je pogranični promet Jugoslavije i Albanije. Na osnovu ovog sporazuma stanovnici albanske pogranične zone mogli su da iznose na jugoslovensko tržište svoje proizvode bez plaćanja carina i taksi. Jugoslovenska pošta pisala je da se taj dan smatrao važnim datumom u ekonomskom oživljavanju Prizrena. Predstavnici poslovnog sveta u Prizrenu nameravali su da uspostave automobilski saobraćaj između Prizrena i Kuksa, gde su do tada samo dvaput nedeljno, utorkom i petkom, saobraćala kola koja

${ }^{13}$ Diplomatski arhiv Ministarstva spoljnih poslova Republike Srbije (DA MSP), Politička arhiva (PA), Albanija, 1947, f.(ascikla) 2, dos.(ije) 2, sign.(atura) 2/105, Izveštaj o sadašnjem stanju na jugoslovensko-albanskoj granici po pitanju dvovlasnika.

${ }^{14}$ Britanci o Kraljevini Jugoslaviji, knj. 2, 314.

${ }^{15}$ Време, 30. 7. 1934.

${ }^{16}$ Новости, 15. 3. 1934. Zbog sve bolje ekonomske saradnje Jugoslavije i Albanije, odnosi Albanije i Italije postali su zategnuti. Naročito se to ispoljilo kada se italijanska flota 23. juna 1934. iznenada pojavila pred Dračem bez odobrenja albanske vlade. Ipak, italijanska vlada odobrila je Albaniji zajam od 60 miliona lira (Društvu za ekonomski razvoj Albanije) u naknadu za njeno obavezivanje da neće učestvovati u Balkanskom paktu. Britanci o Kraljevini Jugoslaviji, knj. 2, 335.

${ }^{17}$ Време, 30. 7. 1934.

18 Albansku pograničnu zonu na sektoru Prizren-Kuks činila su sledeća sela: Rademir, Ćeren, Šulani, Plantani, Vasjat, Čaj, Šećina, Fšate, Buzamase, Štreze, Topojane, Šištevac, Novo Selo, Borje, Orgošt, Štičen, Gostile, Kuks, Podbreg, Bohe (Čezna), Ade, Borzace, Morina, Domne, Đinan, Šalčine, Pogaj, Gorežup, Leš, Đem, Kišan, Muj, Doc, Aurule, Dafka, Nifće, Brekinja, Kolovod, Lojman, Oreška, Bela, Zabade, Pakiš i Košarište. Za ova sela određena su tržišta: Prizren i Vranište i putevi: Prizren-Žur-Kuks i Prizren-Vranište-Globočica i Borje. Bapdap, 17. 7. 1934. 
su istovremeno prevozila i poštu. ${ }^{19}$ Jugoslovenska strana nastojala je time da razvija dobre ekonomske odnose sa Albanijom. Poslanstvo Jugoslavije u Tirani smatralo je da bi trebalo ,bar donekle, da ekonomski vežemo za sebe Albaniju budući da sa Albanijom imamo oko $460 \mathrm{~km}$ granice. Od odnosa koje budemo imali sa tom zemljom zavisiće ne samo mir na granici, već i u dubini naše zemlje, gde živi preko 500.000 Albanaca“. Ipak, politička situacija se nije razvijala u dobrom smeru po jugoslovensko-albanske odnose. Italija je povećavala pritisak na Zogua i Albanija je počela da se okreće od Jugoslavije. ${ }^{20}$ Zogu je 1936. potpisao sa Italijom 12 sporazuma ekonomsko-finansijske prirode. ${ }^{21}$ Jugoslavija je zbog toga posebno obratila pažnju na albansko pitanje u pregovorima sa Italijom, pa je potpisivanjem jugoslovensko-italijanskog pakta 1937, priznat do tada ostvaren italijanski uticaj u Albaniji, a italijanska vlada se obavezala na vojnu uzdržanost u ovoj zemlji. ${ }^{22}$ Ipak, italijanski uticaj u Albaniji doživeo je vrhunac okupacijom Albanije 7. aprila 1939. Time su prestali da važe jugoslovenskoalbanski ugovori, osim sporazuma o pograničnom prometu koji je ostao ,privremeni“. Jugoslovensko-albanske odnose regulisao je Sporazum o proširenju italo-jugoslovenskih sporazuma na Kraljevinu Albaniju od 3. septembra $1939 .^{23}$

\section{Pogranični promet}

Nakon završetka Drugog svetskog rata, na osnovu saradnje u predratnom periodu, Jugoslavija i Albanija uspostavile se najpre diplomatske odnose, a zatim su otpočele da razvijaju političku, ekonomsku i kulturnu saradnju. Krajem februara 1945. sklopile su Ugovor o privrednoj saradnji kojim se označavalo ukidanje ,carinske granice između Jugoslavije i Albanije i da razmena roba između obeju zemalja ugovornica ne podleže nikakvim preprekama“. ${ }^{24}$ Jugoslavija je bila prva država koja je priznala Albaniju 28. aprila $1945 .{ }^{25} \mathrm{Za}$ prvog

\footnotetext{
19 Југословенска пошта, 9. 2. 1935. Dve godine kasnije izvoz u Albaniju se poboljšao, ali je uvoz ostao isti. Izvoz u Albaniju preko pograničnih mesta tokom 1937. iznosio je 10 miliona dinara. Скопски гласник, Скопље, 17. 8. 1929, год. 1, бр. 25, 1-2.

${ }^{20}$ Italija je uveravala Zogua kako je spremna da pomogne u aspiracijama prema Kosovu, Metohiji i Čameriji. Albanija je podržala Italiju kada je odbila da glasa za odluku Društva naroda kojom se u oktobru 1935. tražilo uvođenje ekonomskih sankcija protiv Italije zbog agresije na Etiopiju. U Albaniji je 1935. osnovana emisiona banka čija je uprava bila u Rimu, a banka je trebalo da formira društvo koje bi upisalo zajam od 50 miliona zlatnih franaka za izgradnju javnih radova u Albaniji. Na taj način su Italijani ekonomski ušli u Albaniju. Б. Славковић Мирић, $\mu$. d., 138.

${ }^{21}$ Živko Avramovski, „Italijanska ekonomska penetracija u Albaniji 1925. do 1939“, Istorija 20. veka, br. 5, (1963), 137-224.

22 Jakob Hoptner, Jugoslavija u krizi 1934-1941 (Rijeka: Otokar Keršovani, 1973), 111; Živko Avramovski, „Problem Albanije u jugoslovensko-italijanskom sporazumu od 25. marta 1937“, Historijski pregled, br. 1, (1963), 19-31.

${ }^{23}$ Lj. Dimić, M. Milošević, n. d., 46.

24 Ђ. Борозан, Велика Албанија: поријекло - идеје - пракса, 514.

${ }^{25}$ Jugoslavija 1918-1988. Tematska zbirka dokumenata, priredili Branko Petranović i Momčilo Zečević (Beograd: Rad, 1988), 791.
} 
jugoslovenskog poslanika postavljen je Velimir Stojnić, ${ }^{26}$ a jugoslovenska Vojna misija preimenovana je u Poslanstvo DFJ. ${ }^{27}$

Za saradnju dve države bilo je značajno rešiti pitanje pograničnog prometa. Krajem maja 1945. Velimir Stojnić podneo je jugoslovenskom Ministarstvu spoljnih poslova predlog za regulisanje odnosa duž albansko-jugoslovenske granice. On je smatrao da je neophodno urediti to pitanje jer je vladala nestašica životnih namirnica, pa je bila potrebna veća ekonomska razmena (kupovanje žita na Kosovu i Metohiji, dolazak na pijacu u Debar ili Peć i dr.). Predlagao je da se dopusti dolazak pograničnom stanovništvu Albanije na pijacu u Bitolj, Strugu, Ohrid, Debar, Prizren, Đakovicu, Peć, Podgoricu, Ulcinj i njihovu okolinu u dubinu od $15 \mathrm{~km}$ od granice sa propusnicama od organa Narodne odbrane u blizini granice odnosno u središtima pograničnih potprefektura. Zatim, smatrao je da bi albanska vlada trebalo da dopusti jugoslovenskim državljanima $\mathrm{u}$ pograničnim krajevima da dolaze u Bilište, Podgradec, okolinu Ohridskog jezera i Struge, Piškopeju, Bicaj, Kuks, Skadar i na ostali pogranični teren u dubini od $15 \mathrm{~km}$ sa propusnicom od organa OZNE u sreskim ili okružnim centrima u blizini granice u Makedoniji, na Kosovu i Metohiji i u Crnoj Gori. Takođe, predlagao je da se na granici vrši zajednička, odnosno sporazumna kontrola i obezbeđenje. ${ }^{28}$ Jugoslovensko Ministarstvo inostranih poslova pristalo je na to da se pregovara o slanju albanske delegacije u Beograd. ${ }^{29}$ Odlučeno je da predsednik

${ }^{26}$ Velimir Stojnić (Dobro Selo, kod Bosanske Krupe, 5. april 1916 - Beograd, 28. novembar 1990). Član Komunističke partije Jugoslavije (KPJ) od 1936. godine. Od avgusta 1943, bio je član Oblasnog komiteta KPJ za Bosansku krajinu. Početkom 1944, Vrhovni štab NOV i POJ odredio ga je za člana Vojne misije NOV i POJ u Sovjetskom Savezu i uputio u Moskvu. Posle dva meseca provedena na ovoj dužnosti, vratio se na ostrvo Vis, odakle je avgusta 1944. upućen u Albaniju, kao šef Vojne misije NOV i POJ pri Vrhovnom štabu NOV Albanije. Na toj dužnosti je ostao do kraja aprila 1945, kada je Demokratska Federativna Jugoslavija priznala Narodnu Republiku Albaniju, a on postao prvi poslanik. Oktobra 1945, vratio se u Beograd i postao pomoćnik ministra za Konstituantu, a zatim sekretar i potpredsednik Komisije državne kontrole FNRJ, do 1950. Potom je bio član Saveznog izvršnog veća, Saveznog odbora Socijalističkog saveza radnog naroda Jugoslavije, generalni sekretar Saveza boraca NOR-a Jugoslavije i član generalnog saveta Svetske federacije bivših boraca. Bio je predsednik Komisije za kadrovsku politiku i obrazovanje kadrova Centralnog komiteta SKJ. Za narodnog poslanika Savezne skupštine biran je u više saziva, a jedno vreme je obavljao dužnost predsednika Organizaciono-političkog veća Savezne skupštine. Bio je član Saveta federacije i imao je čin rezervnog general-majora. Za člana Centralnog komiteta Saveza komunista Jugoslavije biran je na šestom, sedmom i osmom kongresu SKJ. Umro je 28. novembra 1990. i sahranjen je u Aleji narodnih heroja na Novom groblju u Beogradu. Nosilac je Partizanske spomenice 1941. i drugih jugoslovenskih odlikovanja, među kojima su Orden narodnog oslobođenja, Orden partizanske zvezde sa zlatnim vencem i Orden zasluga za narod sa zlatnom zvezdom. Ordenom narodnog heroja odlikovan je 24. jula 1953. Vojna enciklopedija, knjiga 9, urednik Nikola Glavežić (Beograd: Redakcija Vojne enciklopedije, 1975).

${ }^{27}$ Милорад Коматина, Енвер Хома и југословенско-албански односи (Београд: Службени лист СРJ, 1995), 42; Zapisnici sa sednica Politbiroa CK KPJ (11. jun 1945-7. jul 1948), priredio Branko Petranović (Beograd: Arhiv Jugoslavije, Službeni list SRJ, 1995), 469-470.

${ }^{28}$ DA MSP, PA, Albanija, 1945, dos. 14, sign. 1882, Predlog za regulisanje odnosa duž albanskojugoslovenske granice, Velimir Stojnić - Ministarstvu inostranih poslova, 29. maj 1945.

29 DA MSP, PA, Albanija, 1945, dos. 14, sign. 1/223, Regulisanje odnosa duž albanskojugoslovenske granice, 16. jun 1945. 
jugoslovenske delegacije bude Svetomir Lazarević, načelnik Konzularnoprivrednog odeljenja Ministarstva. Predstavnici Ministarstva trgovine i snabdevanja bili su Bogdan Stefanović i Slobodan Antonijević, Ministarstva unutrašnjih poslova Živojin Simonović i Rade Mioković, Ministarstva finansija Petar Petijević, v. d. šefa devizno-valutnog odseka bankovno-valutnog odeljenja Andrija Ćetković, v. d. šefa administrativnog odseka Odeljenja carina i Miloš Sofrenović, v. d. šefa Devizne direkcije Narodne banke, ${ }^{30}$ i Ministarstva narodne odbrane major Milić Dejanović. Albanska strana odredila je kao svoje delegate Ramadana Čitakua, ministra finansija, Kočo Taskoa, sekretara Predsedništva Saveta narodnooslobodilačkog antifašističkog veća i Behara Štilu, generalnog sekretara Ministarstva unutrašnjih poslova. ${ }^{31}$

Pregovori su obavljeni 6. jula 1945. Predloženo je vraćanje Odredbi o pograničnom prometu od 22. juna 1926, Uredbe o protokolu o primeni predloga 5 Ugovora o trgovini i plovidbi od 8. maja 1934. i Dopunskog sporazuma Odredbe o pograničnom prometu. Albanci su bili saglasni sa jugoslovenskim predlogom da se pogranična zona ne proširuje. Jugoslovenska strana je smatrala da u Protokol treba da se unesu izmene u nazivima pograničnih vlasti, a isto tako da se pojednostave dvovlasničke propusnice i propusnice za pogranični promet. ${ }^{32}$ Bilo je neophodno da se reši i olakša procedura izdavanja putnih isprava za Albaniju, naročito za pogranična mesta. ${ }^{33}$

Sporazum o pograničnom prometu Jugoslavije i Albanije podrazumevao je da državljani jedne strane ugovornice mogu prelaziti preko granice u pograničnu zonu druge strane ugovornice $i$ to radi odlaska na tržište u cilju prodaje ili kupovine namirnica i potreba, odlaska do mlina radi meljave, do radionice u svrhu opravke ili prerade poljoprivrednih mašina, oruđa, kola, čamaca i sličnih prevoznih sredstava, obrade svojih dvovlasnih imanja, obrade imanja svojih poslodavacadvovlasnika, gonjenja stoke na ispašu ili na zimovanje, pružanja stručne lekarske, akušerske, babičke ili veterinarske pomoći, obavljanja zanata ili posla, prevoza putnika i robe. Pod pograničnom zonom podrazumevao se pojas širine $15 \mathrm{~km} \mathrm{~s}$ jedne i s druge strane duž jugoslovensko-albanske granice. Albanski državljani koji su živeli u pograničnoj zoni mogli su slobodno bez bilo kakvih carina unositi sve proizvode ratarstva i poljoprivrede, voćarske, rudarske, stočne, lova, ribolova, živinarstva i pčelarstva albanskog porekla, kao i proizvode mlekarstva, tkanja, drvodeljstva, kačarstva i dr. Uslov je bio da se proizvodi usmeno prijave i na zahtev carinske kontrole pokažu. U jugoslovenskoj tržišnoj zoni mogli su slobodno da nabavljaju proizvode, ali te količine nisu smele da pređu količine potrebne za utrošak u jednoj nedelji. Jugoslovenski državljani u jugoslovenskoj pograničnoj

${ }^{30}$ DA MSP, PA, Albanija, 1945, dos. 14, sign. 1/232, Zapisnik za regulisanje odnosa duž albansko-jugoslovenske granice, 6. jul 1945.

${ }^{31}$ DA MSP, PA, Albanija, 1945, dos. 14, sign. 1/228, Predlog za regulisanje odnosa duž albansko-jugoslovenske granice, 29. jun 1945.

${ }^{32}$ DA MSP, PA, 1945, Albanija, dos. 14, sign. 1/240, Pogranični saobraćaj sa Albanijom, Veliša Gošović, 11. januar 1946.

${ }^{33}$ DA MSP, PA, Albanija, 1945, dos. 38, sign. 2552, Pomoćnik ministra unutrašnjih poslova M. Radović - Ministarstvu inostranih poslova, 21. decembar 1945. 
zoni mogli su slobodno odlaziti na Skadarsku pijacu uživajući iste slobode kao i stanovnici albanske pogranične zone. Dvovlasnici su mogli takođe slobodno prelaziti granicu, ali samo ukoliko su imali potvrdu o imanju i mogli su ga obrađivati svaki dan ,između izlaska i zalaska sunca“. Oni koji su bili stalno nastanjeni u pograničnoj zoni mogli su dobiti pograničnu kartu i na taj način prelaziti granicu. Lekari, veterinari, babice, akušeri koji su stalno bili nastanjeni u pograničnoj zoni mogli su takođe prelaziti granicu sa pograničnom kartom i obavljati svoj poziv. Pogranične karte i dvovlasničke prelaznice nisu se mogle izdavati licima koja su bila u aktivnoj vojnoj službi. Lica koja su bila osuđena tri puta za krijumčarenje izgubila bi sve povlastice. Svi sporovi i žalbe trebalo je da se rešavaju odmah ili po mogućnosti istog dana od strane nadležnih mesnih vlasti. ${ }^{34}$

Raspisom Ministarstva finansija FNRJ od 31. septembra 1947, kojim su bili regulisani trgovinski odnosi sa inostranstvom, Albanija je isključena iz reda zemalja za koje je važio konvencionalni režim i ona je mogla da izvozi robu u Jugoslaviju uz primenu autonomnih minimalnih stavova opšte carinske tarife, a dvovlasnički promet bio je podvrgnut autonomnom carinskom postupku. ${ }^{35}$ Ovakvim uređenjem pograničnih odnosa granica sa Albanijom faktički nije ni postojala, a prelasci u oba pravca nisu se mogli kontrolisati. ${ }^{36}$

Na Petom plenumu CK KP Albanije, februara 1946, odlučeno je da se Albanija u potpunosti okrene saradnji sa Jugoslavijom. ${ }^{37}$ Istog meseca je obnovljena većina ranijih sporazuma Jugoslavije i Albanije o pograničnom prometu. Ovo pitanje je postavljeno i u aprilu 1946, na Konferenciji o pripremama za trgovinske pregovore Jugoslavije sa Albanijom. ${ }^{38}$ Tada je Oskar Junanić iz Ministarstva inostranih poslova istakao da Albanija predstavlja za Jugoslaviju „,područje specijalnog interesa“. Naglasio je da bi trebalo sprečiti da se Albanija privredno veže za Italiju. Zvonko Pifat iz Ministarstva trgovine je istakao da je pogranični promet otvoren samo u sektoru Prizren-Kuks, a da makedonski i crnogorski sektor još uvek nisu bili otvoreni. Pomoćnik ministra spoljne trgovine Bogdan Crnobrnja je zaključio da je bitno da se povodom pograničnog prometa obrazuje komisija koja bi raspravljala o svim pitanjima u vezi sa tim. ${ }^{39}$

Nakon Konferencije o pripremama za trgovinske pregovore, $\mathrm{u}$ aprilu 1946. potpisan je Ugovor o uspostavljanju pograničnog saobraćaja Jugoslavije i

${ }^{34}$ DA MSP, PA, Albanija, 1945, dos. 9, sign. 2205, Sporazum o pograničnom prometu između DFJ i Albanije i pogranični promet.

${ }^{35}$ DA MSP, PA, Albanija, 1947, f. 2, dos. 2, sign. 2/105, Izveštaj o sadašnjem stanju na jugoslovensko-albanskoj granici po pitanju dvovlasnika.

${ }^{36}$ Благоје К. Павловић, Страдағе Срба 1389-2009 (Београд: Б. К. Павловић: ДТА, 2010), 143.

${ }^{37}$ Перо Златар, Енвер Хоча: политичка биографија (Београд: Рад, 1986), 109-110; Peter R. Prifti, Socialist Albania since 1944. Domestic and Foreign Developments (Cambridge: MIT Press, 1978), 54.

${ }^{38}$ Učestvovali su pomoćnik ministra Crnobrnja, dr Aleksić, V. Ristić i M. Čok iz Ministarstva spoljne trgovine FNRJ, Petar Petijević iz Ministarstva finansija, Josip Šretner i Bradarević iz Ministarstva pomorstva, Oskar Juranić iz Ministarstva inostranih poslova, Havliček iz Ministarstva trgovine i snabdevanja, Ilija Marinković i Ljubiša Perović iz Narodne banke.

${ }^{39}$ DA MSP, PA, Albanija, 1946, f. 2, dos. 18, sign. 4752, Zapisnik sa Konferencije, 29. april 1946. 
Albanije. ${ }^{40}$ Albanski lider Enver Hodža ${ }^{41}$ istakao je u razgovoru sa jugoslovenskim delegatom Josipom Đerđom ${ }^{42}$ da bi bilo dobro da uredba odmah stupi na snagu, a o samom razgovoru Đerđa je dodao komentar da je ,bio vrlo srdačan“ 43 Ipak, postojao je problem funkcionisanja pograničnog saobraćaja i pored toga što je bio regulisan sporazumom. Poslanstvo FNRJ u Albaniji izveštavalo je jugoslovensko Ministarstvo inostranih poslova da su ,mnoga privatna lica snabdevena obično nepropisnim putnim ispravama donosila u Albaniju veće sume našeg novca koji upotrebljavaju za poslove crne berze, krijumčarenje itd. Zatim, opaženo je da mnoge delegacije osobito one iz Crne Gore, Makedonije i Kosova prenose velike količine dinara, opet bez dozvole saveznog Ministarstva finansija. Iz Crne Gore često dolaze trgovačke delegacije koje žele da kupe od Albanaca automobile, željezariju, tekstil itd. sa velikim sumama našeg novca. Iz Ulcinja je stigao pre dva meseca direktor solane sa 300.000 dinara. Juče je iz Prizrena doputovao Tomović Dušan, direktor radio-stanice sa 160.000 dinara sa dva druga radi kupovine nekih stvari. Pošto je službeni kurs Državne albanske banke 13.50 dinara=1 franak, a na crnoj berzi može da se dobije 1 franak za 8 dinara, to svaka kupovina na toj bazi znači obaranje vrednosti naše monete“" ${ }^{44}$ Jugoslovensko Ministarstvo finansija je na Đerđin izveštaj odgovorilo da su ,,preduzete potrebne mere da bi se

${ }^{40}$ Arhiv Jugoslavije (AJ), fond 112, Tanjug, 112-792-793, 17. april 1946.

${ }^{41}$ Enver Hodža (Đirokastra, 16. oktobar 1908 - Tirana, 11. april 1985), vođa Narodne Republike Albanije od kraja Drugog svetskog rata do svoje smrti, kao prvi sekretar Komunističke albanske partije rada. Bio je premijer Albanije 1944-1954. i ministar spoljnih poslova 1946-1953. Više o Enveru Hodži: М. Коматина, н. d.; Ben Fowkes, Eastern Europe 1945-1969. From Stalinism to Stagnation (Harlow [etc.]: Longman, 2000), 141; Бленди Февзиу, Енвер Хоца: прва биографија заснована на документи од личната архива и на исповедите на оние што го познаваа (Скопје: Фондација Отворено општество - Македонија, 2014); Милчо Балевски, Албанија по Енвер Хоиа (Скопје: Македонска книга, 1987); П. Златар, н. д.; Spasoje Đaković, Fadilj Hodža i Enver Hodža (Beograd: Naučna knjiga, 1989); Vladimir Adamović, „Enver Hodža: mehanizmi vlasti“, Ideje: jugoslovenski studentski časopis, br. 5-6, (1987), 162-171; Vasfi Baruti, Enver Hoxha në optikë të re (Tiranë: Uegen, 2012); Blendi Fevziu, Enver Hoxha (Tiranë: UET Press, 2011); Kastriot Dervishi, Kryeministrat dhe ministrat e shtetit shqiptar në 100 vjet (Tiranë: 55, 2012), 136; Kastriot Dervishi, Lëvizja Komuniste në vitet 1924-1944 dhe formimi i PKSH-së (Tiranë: 55, 2016), 188; Robert Elsie, A biographical dictionary of Albanian history (London... [etc.]: I. B. Tauris, 2013), 207-208.

42 Josip Đerđa (Arbanasi, kod Zadra, 11. februar 1911 - Beograd, 18. februar 1990), član KPJ od 1934. Bio je sekretar Agitpropa Centralnog komiteta KP Hrvatske i uređivao Vjesnik do januara 1943. Pokrenuo i do polovine 1944. uređivao list Naprijed, glasilo KPH. Nakon rata radio je kao načelnik odeljenja u Prezidijumu vlade FNRJ, ali je ubrzo prešao u diplomatsku službu. Bio je ambasador Jugoslavije u Albaniji (1945-1948), Mađarskoj, Bugarskoj (1948-1949), Indiji (19501951), Burmi i Egiptu (1956-1963). Biran je u najviše organe političkih organizacija: član CK SKH (1948-1958) i Predsedništva SSRN Jugoslavije (1966-1970). U više mandata bio je poslanik u Saveznoj skupštini (1963-1972), pa njen potpredsednik (1970-1972). Na tu funkciju podneo je ostavku 1972, objavivši da se ne slaže s prekidom politike koju je sprovodilo rukovodstvo SRH do 21. sednice Predsedništva SKJ u Karađorđevu 1971. Umro je 18. februara 1990. u Beogradu. Hrvatski biografski leksikon, knjiga III (Zagreb: „Leksikografski zavod Miroslav Krleža“, 1993); Ko je ko u Jugoslaviji: jugoslovenski savremenici (Beograd: Hronometar, 1970).

${ }^{43}$ DA MSP, PA, Albanija, 1946, dos. 4, sign. 4307, Đerđa - Ministarstvu spoljnih poslova, 15. april 1946.

${ }^{44}$ DA MSP, PA, Albanija, 1946, dos. 23, sign. 7003, Prenos dinara u Albaniju, 8. decembar 1945. 
sprečilo ilegalno iznošenje našeg novca u inostranstvo“, a molilo je i da Jugoslovensko poslanstvo u Tirani spreči slične slučajeve. ${ }^{45}$

Radi nastavka i učvršćivanja saradnje Jugoslavije i Albanije, jugoslovensko rukovodstvo pozvalo je Envera Hodžu sredinom 1946. u zvaničnu posetu Jugoslaviji. ${ }^{46} \mathrm{Za}$ vreme boravka albanskog rukovodstva u Beogradu, 1. jula 1946. potpisani su sporazumi o privrednoj saradnji, plaćanjima i kreditima. ${ }^{47}$ Najavljeno je sklapanje sporazuma o prijateljstvu i pomoći, što je učinjeno 9. jula 1946. u Tirani. Rešenjem Ministarstva spoljne trgovine FNRJ od jula 1946, dvovlasnički promet regulisan je po povlašćenom režimu uvoza i izvoza bez uvoznih i izvoznih odobrenja za predmete koji su ulazili u okvir dvovlasničkog prometa. Oktobra 1946. zaključen je sporazum o nerobnom plaćanju prema kome su dvovlasnici mogli plaćati obaveze iz osnova poreza i drugih dažbina preko narodnih banaka. Konačno, na osnovu Ugovora o usklađivanju privrednih planova o carinskoj uniji i izjednačenju valute 27. novembra 1946, ukinuta je carinska granica između Jugoslavije i Albanije. ${ }^{48}$ Prema ovom ugovoru, valute obeju zemalja trebalo je da postanu zakonito platežno sredstvo u svim pograničnim srezovima duž albansko-jugoslovenske granice i da se dozvoli slobodna zamena leka i dinara u svim krajevima i mestima na celoj teritoriji obe zemlje. ${ }^{49}$

Posle potpisivanja ugovora o carinskoj uniji i izjednačavanju valute, svako ko je putovao u Albaniju na osnovu putne isprave dobijao je 5.000 leka i obratno. Takođe, svako ko je želeo da ide iz jedne u drugu državu radi robnog prometa dobijao je ček na 10.000 leka odnosno dinara i slobodno je kupovao robu u Albaniji odnosno Jugoslaviji. Dozvole za uvoz i izvoz više nisu postojale, već se od narodnih banaka automatski dobijao novac za plaćanje kupljene robe. Po pravilu trebalo je da postoji devizno-valutna kontrola na granici koja bi kontrolisala iznošenje $\mathrm{i}$ unošenje nedozvoljenih količina jugoslovenske odnosno albanske valute. Međutim, praktično od ušća Bojane do planine Bogićevice na granici Jugoslavije i Albanije nisu postojali nikakvi državni organi posle sporazuma o carinskoj uniji. ${ }^{50}$

Albansko poslanstvo tražilo je od Ministarstva inostranih poslova FNRJ da izbeglice iz Kuksa, koje su se vraćale sa Kosova i Metohije zbog siromaštva, mogu da izvezu svoje poljoprivredne proizvode u Albaniju. ${ }^{51}$ Sa tim se jugoslovenska vlada složila i dozvolila je albanskim izbeglicama da mogu poneti poljoprivredne proizvode u Albaniju. ${ }^{52} \mathrm{U}$ primeni Sporazuma javljali su se i pro-

${ }^{45}$ DA MSP, PA, Albanija, 1946, dos. 23, sign. 7433, Prenos dinara u Albaniju, 22. decembar 1945.

${ }^{46}$ Hronologija revolucionarne delatnosti Josipa Broza Tita, priredili Branislav Ilić i Vojislav Ćirković (Beograd: Export-press, 1978), 107.

${ }^{47}$ М. Коматина, н. д., 48.

${ }^{48}$ DA MSP, PA, Albanija, 1947, f. 2, dos. 2, sign. 2/105, Izveštaj o sadašnjem stanju na jugoslovensko-albanskoj granici po pitanju dvovlasnika.

${ }^{49}$ AJ, fond 50, Predsedništvo Vlade FNRJ, f. 48, Dopunski ugovor, 27. novembar 1946.

${ }^{50}$ DA MSP, PA, Albanija, 1947, f. 2, dos. 2, sign. 2/105, Izveštaj o sadašnjem stanju na jugoslovensko-albanskoj granici po pitanju dvovlasnika.

${ }^{51}$ DA MSP, PA, Albanija, 1947, f. 2, dos. 16, sign. 2/363, Albansko poslanstvo - Ministarstvu inostranih poslova FNRJ, 20. januar 1947.

${ }^{52}$ DA MSP, PA, Albanija, 1947, f. 2, dos. 16, sign. 2/365, Načelnik političkog odeljenja Jože Brilej - Glavnom narodnom odboru autonomne oblasti Kosova i Metohije u Prištini, 10. februar 1947. 
blemi. Tako je Ministarstvo unutrašnjih poslova Crne Gore izveštavalo jugoslovensko Ministarstvo inostranih poslova da su albanske vlasti davale razne dozvole za prelaz jugoslovensko-albanske granice stanovnicima Albanije nastanjenim van pogranične zone, naročito u Skadru. ${ }^{53}$

\section{Dvovlasnička imanja}

Problem na jugoslovensko-albanskoj granici bila su i dvovlasnička imanja. Prema izveštaju sekretara Poslanstva FNRJ u Tirani Ljube Osterca, u oblasti Skadra prilikom pristupanja primeni agrarne reforme utvrđeno je da je 60 jugoslovenskih porodica posedovalo imanja na ovoj teritoriji, a ne 117 kao što je bilo poslato u noti Ministarstva inostranih poslova. Izgleda da je razlika bila u tome što su porodice napustile Albaniju, a kada su počela premeravanja nisu došli zainteresovani niti su poslali svoje zastupnike. Pri sprovođenju Zakona o agrarnoj reformi jedan deo tih imanja dodeljen je albanskim zemljoposednicima dok se ostali deo nije iskorišćavao. U naknadu im je bilo dato nešto manje zemlje koja se nalazila na jugoslovenskoj teritoriji a bila je svojina albanskih državljana data jugoslovenskim zemljoradnicima. Zato je Osterc smatrao da pomenuta zemljišta treba da se podvrgnu eksproprijaciji. ${ }^{54}$

\begin{tabular}{|c|c|c|}
\hline \multicolumn{3}{|c|}{ Brojno stanje dvovlasnika } \\
\hline & jugoslovenskih & albanskih \\
\hline Područje Crne Gore & 243 & 132 \\
\hline Područje Kosova i Metohije & 114 & 192 \\
\hline Područje Makedonije & 76 & 249 \\
\hline Ukupno & 433 & 573 \\
\hline \multicolumn{3}{|c|}{ Površine dvovlasničkih imanja } \\
\hline & jugoslovenskih & albanskih \\
\hline Područje Crne Gore & 649,922 ha & 173,446 ha \\
\hline Područje Kosova i Metohije & $692,17 \mathrm{ha}$ & $309,03,45$ ha \\
\hline Područje Makedonije & 54,9 ha & 325,8765 ha \\
\hline \multicolumn{3}{|c|}{ Dvovlasnička imanja prema kulturama } \\
\hline & jugoslovenskih & albanskih \\
\hline \multicolumn{3}{|l|}{ Područje Crne Gore } \\
\hline Oranice & 94,276 ha & 59,878 ha \\
\hline Livade & $116,298 \mathrm{ha}$ & 54,600 ha \\
\hline Pašnjaci & $370,188 \mathrm{ha}$ & 38,948 ha \\
\hline Šume & 69,160 ha & 20,020 ha \\
\hline
\end{tabular}

${ }^{53}$ DA MSP, PA, Albanija, 1947, f. 2, dos. 2, sign. 4878, Ministarstvo unutrašnjih poslova - Ministarstvu inostranih poslova FNRJ, 15. januar 1947.

54 DA MSP, PA, Albanija, 1947, f. 2, dos. 2, sign. 6396, Jugoslovenski državljani dvovlasnici nepokretnih imanja na albanskoj teritoriji i agrarna reforma, 2. januar 1947. 


\begin{tabular}{|l|l|l|}
\hline \hline Područje Kosova i Metohije & & \\
\hline Oranice & $22,15 \mathrm{ha}$ & $182,30 \mathrm{ha}$ \\
\hline Livade & $39,50 \mathrm{ha}$ & $62,44,45 \mathrm{ha}$ \\
\hline Šume & $630,52 \mathrm{ha}$ & $63,79 \mathrm{ha}$ \\
\hline Vinogradi & & $0,50 \mathrm{ha}$ \\
\hline
\end{tabular}

Stanje dvovlasnika i njihovih imanja na jugoslovensko-albanskoj granici 1947. (DA MSP, PA, Albanija, 1947, fascikla 2, dosije 2, signatura 2/105, Izveštaj o sadašnjem stanju na jugoslovensko-albanskoj granici po pitanju dvovlasnika)

Početkom februara 1947, formirana je komisija za rešavanje sporova na dvovlasničkim imanjima, koja je radila u februaru i martu. Komisiju su činili, sa jugoslovenske strane, Drago Košmrlj, Ljubomir Veljković, Aleksandar Maksimovski i Dimitar Krkov, a sa albanske Halil Zejneli i Masar Derviš. Bilo je bitno da se očuvaju dvovlasnička imanja iz nekoliko razloga, pre svega jer je stanovništvo duž čitave granice većinom bilo albanske nacionalnosti i u rodbinskim vezama. Komisija se uverila da se ne može izvršiti zamena dvovlasničkih imanja, jer ona ni po broju ni po kvalitetu nisu bila jednaka. Kada je izvršena eksproprijacija zemljišta, eksproprisana je zemlja od 39 lica sa površinom oko 100 hektara. Eksproprisani vlasnici mogli su se svrstati u sledeće kategorije: nezemljoradnici - trgovci, zanatlije, učitelji i drugi, zemljoradnici i izbeglice iz Drugog svetskog rata. Pri tom su se pojavili mnogi sporovi. Najviše problema bilo je na crnogorskom delu granice, naročito u Barskom srezu. Tu su agrarne vlasti Albanije prilikom sprovođenja agrarne reforme 1946. eksproprisale skoro sve jugoslovenske dvovlasnike bez zakonskog osnova i bez prethodnog dogovora sa jugoslovenskim vlastima. Postojao je spor između stanovnika sela Steblevo (srez Šupenza) i sela Lakovica (Struški srez). Ovaj spor je nastao zbog povlačenja granice kada je atar sela Stebleva presečen i 9 porodica ovog sela napustilo svoju zemlju na albanskoj teritoriji, prešlo na jugoslovensku teritoriju i nastanilo se na mestu tadašnjeg sela Lakavice, uzevši imanje od oko 80 porodica sela Stebleva. Ova situacija je trajala do 1941. kada su seljaci sela Stebleva počeli ponovo da obrađuju svoju zemlju u selu Lakavici sve do kraja Drugog svetskog rata kada ih je uspostavljanje granice ponovo sprečilo da obrađuju zemlju. Komisija je rešila da se seljacima iz sela Stebleva preda njihova zemlja u selu Lakovica na obradu, kao i da se seljacima iz sela Lakovica preda u vlasništvo njihova zemlja u selu Steblevu. Problem su imali i stanovnici sela Rajce - srez Libražd, koji nisu bili zadovoljni zato što im jugoslovenske vlasti nisu dopuštale ispašu u selu Malo Vlaje, zbog puštanja koza i seče šuma. Na teritoriji srezova Podgradec i Libražd nije vršena eksproprijacija imanja jugoslovenskih državljana, za razliku od teritorije albanskih srezova Šupenza i Piškopeja gde je vršena. Konstatovan je i slučaj da su albanske vlasti eksproprisale zemlju braće Meti i Rasima Daci koji su bili albanski državljani, a koji su imali 4 ha zemlje i na jugoslovenskoj teritoriji. Ta zemlja je dodeljena albanskom državljaninu Hadži Muču iz sela Blato (Albanija), a da pritom mesne jugoslovenske vlasti nisu 
preduzele ništa po tom pitanju. Komisija je rešila ovaj spor tako što je vratila zemlju mesnim narodnim vlastima u Debru.

Prema izjavi predstavnika albanskog Ministarstva poljoprivrede Mesara Derviša bilo je predviđeno da jugoslovenski dvovlasnici dobiju zemljište u nadoknadu, ali to nije prihvaćeno. Eksproprijacija zemlje jugoslovenskih državljana koji nisu bili zemljoradnici smatrana je ispravnom, kao i onih koji su se zemlje odrekli pisanom izjavom. Komisija je odlučila da se zemljište vrati, ali samo onima koji u Jugoslaviji nisu imali dovoljno zemlje. Fizička primopredaja zemlje trebalo je da se izvrši do 20. marta 1947. Onima koji su napustili zemlju u toku Drugog svetskog rata a zemlja im je bila eksproprisana, trebalo je da im se vrati. Od vraćanja u vlasništvo izuzimale su se površine pašnjaka i šuma koje su prema albanskom zakonu ušle u sastav „opštenarodne imovine“. U slučajevima kada je dvovlasnička zemlja zasejana jesenjim usevima, dalje radove trebalo je da izvrši vlasnik imanja i da podeli prinos sa licem koje je zemlju zasejalo. Od dana donošenja rešenja ove komisije do 31. oktobra 1948. „nisu mogle da se donose odluke od agrarnih vlasti nijedne narodne republike, kojima bi se oduzimala zemlja dvovlasnika“.

Komisija je za pitanja koja nije mogla da reši tražila od vlada FNRJ i NRA da donesu zajedničko rešenje. Tako su na Kosovu i Metohiji obe vlade morale da donesu sporazumno rešenje za korišćenje pašnjaka, jer su pašnjaci i šume bili nacionalizovani i u Jugoslaviji i u Albaniji. Takođe, vlade obe zemlje morale su da reše i probleme nastale prilikom povlačenja granice. Tako su mnogim selima odsečene njihove planine (pašnjaci, šume, suvati i dr.) i pripale teritoriji susedne države. Na sektoru crnogorsko-albanske granice seljaci iz sela Štoj, Bratića, Fraskanela i drugih u Barskom srezu (oko 70 porodica) nisu mogli da izgone stoku na pašnjake sela Vrnoš, Dedaj, Mdžet i Škrelj u Albaniji jer nisu mogli da dobiju dvovlasničku kartu. Seljaci u Hoti u Podgoričkom srezu (73 porodica) nisu mogli da izgone stoku u Kopite, Psjeri, Bezgažu i druga sela u Albaniji, jer su im to ometale porodice iz plemena koja su tamo živela. Takođe, Komisija je predložila vladama da pretresu pitanje izdavanja dvovlasničkih karata. Bilo je neophodno da se SNO pobrinu da mesne vlasti pravovremeno izdaju svim dvovlasnicima susedne države uverenja da poseduju teritoriju tih mesnih vlasti i da SNO pravovremeno izdaju dvovlasničke karte svim svojim dvovlasnicima da bi mogli nesmetano da obrađuju zemlju.

Komisija je u svom radu naišla i na žalbe dvovlasnika o nepogodnom prelazu granice. Seljaci iz Šištevca u Albaniji imali su livade uz granicu udaljene samo kilometar od kuće, dok im je prelaz preko granice određen $15 \mathrm{~km}$ daleko od sela. Na granici prema Kosovu i Metohiji jedan broj seljaka sa obe strane koristio je ispašu, a većina nije mogla zato što im vlasti nisu dozvoljavale ili zato što im je određeno mesto prelaska granice bilo predaleko.

$\mathrm{Na}$ kraju rada Komisija je zaključila da postoji nezadovoljstvo zbog nepravilnog sprovođenja agrarne reforme od strane albanskih organa prema jugoslovenskim državljanima, koje su vršili delegati iz Ministarstva poljoprivrede mada „nisu bili politički na visini zadataka“. Ipak, na terenu Komisija nije nai- 
šla na „stvari koje bi ometale prijateljske i zdrave odnose pograničnog stanovništva“. Većina krajeva na crnogorskom delu granice gravitirala je ka Albaniji, dok su na Kosovu i Metohiji i delu Makedonije albanski pogranični krajevi bili okrenuti ka Jugoslaviji. Pogranični krajevi su se međusobno pomagali. Tako je Komisija blizu Plava i Gusinja naišla na slučajeve gde su dvovlasnici - jugoslovenski državljani, otišli u Albaniju da glasaju na izborima ondašnjih mesnih vlasti. U Dragaškom srezu seljaci su na zajedničkim sastancima rešavali probleme. Takođe, albansko selo Šištevac odlučilo je da će pomoći susednom jugoslovenskom selu u izgradnji puta. ${ }^{55}$

Nedoumice u rešavanju dvovlasničkih pitanja izazivale su pre svega putne isprave koje su dvovlasnici morali da poseduju. Jugoslovenski otpravnik poslova Drago Košmrlj izveštavao je Ministarstvo inostranih poslova da jugoslovenske pogranične vlasti, prema navodima organa unutrašnje sekcije Skadarske prefekture, ne dopuštaju prelazak na jugoslovensku teritoriju albanskim državljanima koje su im davale pravo kretanja u dubinu od 15 i 30 km, jer su primili naređenje da mogu puštati u zemlju samo one albanske državljane koji su snabdeveni redovnim putnim ispravama. ${ }^{56}$ Takođe, pomoćnik načelnika Prvog regionalnog odeljenja Bl. Hadži Panzov izveštavao je MIP da je u interesu bolje jugoslovensko-albanske saradnje predloženo albanskoj vladi uprošćavanje formalnosti oko izdavanja i overavanja pograničnih karata, dvovlasničkih karata i propusnica za stanovništvo obeju zona. ${ }^{57}$ Ono što je trebalo da doprinese rešavanju problema bilo je ukidanje viza na pasošima između Jugoslavije i Albanije u avgustu $1947 .{ }^{58}$ Ipak, postojalo je nezadovoljstvo uspostavljenim dogovorima. U oktobru 1947 , Poslanstvo FNRJ u Tirani izveštavalo je jugoslovensko Ministarstvo inostranih poslova da je na pograničnim punktovima u Draču, Tirani, Rožaju i Ćafasanu vršen pregled ,ne samo stvari do u sitnice, nego se pretresaju svi putnici bez obzira pa čak i deca“. Napominjalo se da se muškarci na pograničnom punktu Ćafasan „upotrebljavaju i za pregled stvari žena“. 59

Jugoslovensko-albanski odnosi krenuli su silaznom putanjom od sredine 1947, naročito nakon posete Envera Hodže Moskvi, kada se Albanija okrenula Sovjetskom Savezu. ${ }^{60}$ To se odrazilo na privrednu saradnju Jugoslavije i Albanije,

${ }^{55}$ DA MSP, PA, Albanija, 1947, f. 2, dos. 2, sign. 10666, Izveštaj o radu Komisije za rešavanje sporova na dvovlasničkim imanjima, 2. mart 1947.

${ }^{56}$ DA MSP, PA, Albanija, 1947, f. 2, dos. 2, sign. 45761, Drago Košmrlj - Ministarstvu inostranih poslova FNRJ, 28. mart 1947.

${ }^{57}$ DA MSP, PA, Albanija, 1947, f. 2, dos. 2, sign. 2/66, Pomoćnik načelnika Prvog regionalnog odseka -Ministarstvu inostranih poslova FNRJ, 13. jun 1947.

58 DA MSP, PA, Albanija, 1947, f. 2, dos. 3, sign. 414511, Telegram Ministarstvu inostranih poslova FNRJ, 5. avgust 1947.

${ }^{59}$ DA MSP, PA, Albanija, 1947, f. 3, dos. 10, sign. 420163, Poslanstvo FNRJ - Ministarstvu inostranih poslova FNRJ, Pregled i pretres putnika na albansko-jugoslovenskoj granici, 11. oktobar 1947.

${ }^{60}$ Enver Hodža je posetio Moskvu 14-26. jula 1947. U albanskoj delegaciji bili su još Koči Dzodze, Hisni Kapo, Manol Konomi i Fadil Pačrami, kao i sovjetski otpravnik poslova u Tirani Čuvahin (AJ, fond 112, Tanjug, 112-815-816, 14. jul 1947). Pored razgovora o privrednim i kulturnim odnosima između dve zemlje, SSSR je odobrio Albaniji mali kredit i obećao da će 
jer je uticalo na sprovođenje ekonomskih ugovora. ${ }^{61}$ Nesuglasica je bilo i što se tiče dvovlasničkih imanja. Krajem decembra 1947. Ministarstvo unutrašnjih poslova FNRJ obavestilo je jugoslovenski MIP da su albanske vlasti prilikom izvođenja agrarne reforme oduzele imanja od oko 250 jugoslovenskih dvovlasnika koji su bili na albanskoj teritoriji. Radi rešavanja problema predloženo je da se osnuje mešovita komisija, a albanska vlada se saglasila sa tim. ${ }^{62} \mathrm{U}$ januaru 1948. odlučeno je da sa jugoslovenske strane u ovu komisiju uđe po jedan predstavnik MUP-a, Komisije za agrarnu reformu i kolonizaciju, MIP-a i makedonske odnosno crnogorske vlade. Komisija je kao konsultativni organ trebalo da ima po jednog predstavnika sreza na čijem bi terenu radila. Predstavnik MIP-a trebalo je da bude savetnik Poslanstva u Tirani Drago Košmrlj. ${ }^{63}$ Komisiju su činili, pored Košmrlja, Ljubomir Veljković, Dušan Asanović i Kosa Vrbica, sa jugoslovenske strane, a Halil Zejneli, Masar Derviš i Bako Culić, sa albanske. Albanska strana je predložila da se sastanu u Skadru 10. ili 15. februara i da otpočnu sa radom. ${ }^{64}$ Sastanak je održan 10. februara 1948, prema izveštaju J. Đerđe u ,vrlo dobroj atmosferi“. Ipak ni Albanci ni Jugosloveni nisu imali dovoljno podataka prema kojima su mogli da započnu rad. Trebalo je preko Oblasnog odbora Kosmeta i makedonske vlade uputiti Komisiji sve podatke o dvovlasničkim sporovima. ${ }^{65}$

Šef albanskog dela komisije, prema izveštaju Košmrlja, bio je na sastanku 17. februara sa Enver Hodžom i Hisni Kapom. Hodža se tada saglasio da se

dati jednu fabriku za proizvodnju poljoprivrednih mašina. Stefanaq Pollo, Historie de l'Albanie (Roanne: Editions Horvath, 1974), 308; Александар Животић, „Југославија и јачање совјетског утицаја у Албанији 1947-1948“, Токови историје, бр. 3, (2009), 109.

${ }^{61} \mathrm{U}$ jugoslovensko-albanskim odnosima dolazi do krize koja se ispoljavala na svim poljima. $U$ albanskoj štampi se manje pisalo o Jugoslaviji, a potencirala se uloga Sovjetskog Saveza u albanskoj privredi. Ipak, albansko rukovodstvo je još uvek pokušavalo da održi ravnotežu između Jugoslavije i SSSR-a. Александар Животић, Југословенско-совјетске војне супротности (1947-1957). Искушења савезништва (Београд: Архипелаг, Институт за новију историју Србије, 2015), 160; Miodrag Marović, Balkanski džoker: Albanija i Albanci: istorijska hronika nastajanja i razvoja albanskog pitanja (Bar: Kulturni centar, 1995), 407; Bogumil Hrabak, „Političko-bezbednosna situacija u Albaniji 1945-1947“, Istorija 20. veka, br. 1-2, (1990), 77-115; Đorđe Borozan, „Jugoslovensko-albanski odnosi u prvoj deceniji Hladnog rata“, u: Velike sile i male države u Hladnom ratu 1945-1955, Slučaj Jugoslavije, urednik Ljubodrag Dimić (Beograd: Katedra za istoriju Jugoslavije - Filozofski fakultet u Beogradu, Arhiv Jugoslavije, 2005), 131-139.

${ }^{62}$ DA MSP, PA, Albanija, 1948, f. 4, dos. 16, sign. 4/514, Pomoćnik ministra dr V. Velebit Predsedništvu Vlade FNRJ, 22. decembar 1947. O tom problemu je i krajem aprila izveštavao Ministarstvo inostranih poslova FNRJ šef odseka pograničnog prometa Joco Katana. On je pisao da su albanske vlasti na osnovu Zakona o agrarnoj reformi oduzeli imanja od oko 250 dvovlasnika koji su se nalazili na albanskoj teritoriji, i molio je da se preduzmu adekvatne mere da bi se ta situacija rešila. DA MSP, PA, Albanija, 1947, f. 2, dos. 2, sign. 8374, Šef odseka pograničnog prometa Joco Katana - Ministarstvu inostranih poslova FNRJ, 22. april 1947.

${ }^{63}$ DA MSP, PA, Albanija, 1948, f. 4, dos. 16, sign. 4/518, Telegram Simića - Ministarstvu inostranih poslova FNRJ, 21. januar 1948.

${ }^{64}$ DA MSP, PA, Albanija, 1948, f. 4, dos. 16, sign. 42929, Telegram Đerđe - Ministarstvu inostranih poslova FNRJ, 31. januar 1948.

65 DA MSP, PA, Albanija, 1948, f. 4, dos. 16, sign. 43918, Telegram Đerđe - Ministarstvu inostranih poslova FNRJ, 11. februar 1948. 
rad odvijao u „najpotpunijem skladu“ sa jugoslovenskim predstavnicima. ${ }^{66}$ Hisni Kapo je u pismenoj formi izrazio saglasnost u rešavanju dvovlasničkih pitanja. On je naveo da bi trebalo da se, ,za zemljišta koja su bila oduzeta agrarnom reformom i jednima i drugima, izuzimajući ona koja su bila državna dobra, da drugo povoljno zemljište“. U pogledu pašnjaka, bili su saglasni da se upotrebljavaju kao i u prethodnom periodu. Kapo je smatrao da treba odrediti po jedno lice za svaku stranu da bi se izbegle greške u sprovođenju odluka. ${ }^{67}$

Komisija je, prema izveštaju Košmrlja, 18. februara završila rad na terenu na sektoru crnogorsko-albanske granice. Na tom delu granice utvrđene su greške u oko 220 slučajeva nastale primenom agrarne reforme prema jugoslovenskim dvovlasnicima u Albaniji. Prema zapisniku Mešovite komisije prikupljeni su podaci za granični sektor Sreskog narodnog odbora (SNO) Bar, SNO Skadar i SNO Koplik. Nacionalni sastav bio je uglavnom albanski i nije bio redak slučaj da su delovi iste porodice bili stanovnici obeju država. Prema zaključku komisije, po istorijskom nastanku delili su se u tri grupe: 1) migracije brđana stočara prema ravnicama, kao i pravljenje kuća u brdima onih koji su bili u močvarnim ravnicama, 2) davanjem miraza udavačama kao i preseljavanjem pojedinih delova porodica na jednu i drugu stranu granice i 3) dvovlasnička imanja nastala kupovanjem, nasleđivanjem i pomeranjem granice kroz istoriju. Na teritoriji SNO Bar bilo je oko 230 seljaka koji su imali zemlju u NR Albaniji. To je bilo oko 150 hektara oranice, 70 hektara livade i 52 hektara pašnjaka i šuma. Bilo je 86 dvovlasnika državljana NR Albanije sa posedom od oko 62 hektara oranica, 29 hektara livada i 67 hektara pašnjaka i šume. U SNO Skadar i Koplik pri sprovođenju agrarne reforme bilo je nepravilnosti. Komisija je rešila da se eksproprisana zemlja u ovim delovima vrati u vlasništvo i preda na obradu. ${ }^{68}$ Košmrlj je predložio da obe vlade donesu zajedničko rešenje kojim bi se omogućilo stočarima državljanima FNRJ da izgone stoku na pašnjake u NRA gde su uvek izgonili, i obrnuto, kao i da se efikasnije izdaju dvovlasničke karte. Svi sreski narodni odbori u FNRJ trebalo je da nabave od mesnih narodnih vlasti Albanije, i obrnuto, uverenja da poseduju svoje imanje na teritoriji tog MNO. Na bazi tih uverenja SNO su izdavali dvovlasnicima dvovlasničke karte kojima su nesmetano prelazili granicu. Što se tiče žalbi povodom nepogodnih mesta za prelazak granice, Komisija je predložila da se to reši određivanjem povoljnijih prelaza. ${ }^{69}$

Svi započeti projekti i predložena rešenja prekinuti su otvorenom krizom u jugoslovensko-albanskim odnosima nakon objavljivanja Rezolucije Informbiroa 28. juna 1948. Centralni komitet Komunističke partije Albanije podržao je 29.

${ }^{66}$ DA MSP, PA, Albanija, 1948, f. 4, dos. 17, sign. 55517, Poslanstvo FNRJ u Tirani Ministarstvu inostranih poslova FNRJ, 18. februar 1948.

${ }^{67}$ DA MSP, PA, Albanija, 1948, f. 4, dos. 17, sign. 426551, Ministarstvo spoljnih poslova Albanije - Ministarstvu inostranih poslova FNRJ, 30. mart 1948.

${ }^{68}$ DA MSP, PA, Albanija, 1948, f. 4, dos. 17, sign. 4/541, Zapisnik mešovite komisije, 20. februar 1948

69 DA MSP, PA, Albanija, 1948, f. 4, dos. 17, sign. 413518, Poslanstvo FNRJ u Tirani Ministarstvu inostranih poslova FNRJ, 18. maj 1948. 
juna Rezoluciju i okrenuo se protiv KPJ. ${ }^{70}$ To se manifestovalo na svim poljima, uklonjene su sa svih javnih mesta slike J. B. Tita, ${ }^{71}$ prekinuti su započeti radovi i projekti, ${ }^{72}$ jugoslovenski stručnjaci su morali da napuste Albaniju, a albanska vlada otkazala je sve privredne sporazume i protokole zaključene između dve zemlje (osim Ugovora o prijateljstvu i uzajamnoj pomoći). ${ }^{73}$ Zbog svega navedenog na jugoslovensko-albanskoj granici bila je povećana opreznost. Jugoslovensko Ministarstvo inostranih poslova smatralo je da treba preduzeti potrebne mere da bi se izbegli pogranični incidenti. ${ }^{74}$ Uskoro je, zbog novonastale situacije, Jugoslavija obustavila do daljeg sve isporuke robe za Albaniju, ${ }^{75}$ a zatim je zatvorila jugoslovensko-albansku granicu. To nije bilo jednostavno sprovesti, jer nije ni postojao pravi granični režim na tom prostoru. Lokalno stanovništvo je imalo naviku da slobodno prelazi granicu, a i tokom godina saradnje granična obeležja bila su gotovo zapostavljena. ${ }^{76}$ Tako su se javili problemi i po dvovlasničkom pitanju, jer je bilo slučajeva da su Albanci žnjeli njive u graničnom pojasu i nosili to žito preko granice, kao i da su uzimali snopove. ${ }^{77}$

Definitivan razlaz sa Jugoslavijom i okretanje SSSR-u Enver Hodža je pokazao na 11. plenumu, održanom 13-24. septembra 1948. Tom prilikom naglašeno je da je ,politička linija partije oštećena pod uticajem jugoslovenskog rukovodstva“" ${ }^{78}$ Konačno na Prvom kongresu KPA, ${ }^{79}$ koji je održan od 8. do 22.

70 А. Животић, „Југославија и јачање совјетског утицаја у Албанији 1947-1948“, 110-111.

${ }^{71}$ AJ, fond 507, CK SKJ, 507/9, Komisija za međunarodne veze, 1/1-190, 30. jun 1948.

${ }^{72}$ Obustavljeni su radovi na pruzi Skadar-Titograd i na trasiranju pruge Skadar-Kuks, zato što je te radove izvodilo Jugoslovensko-albansko mešovito društvo. Prema naređenju ministra industrije NR Albanije bila je obustavljena isporuka nafte i bitumena za Jugoslaviju 30. juna 1948. AJ, CK SKJ, 507/9, Komisija za međunarodne veze, 1/1-191.

${ }^{73}$ AJ, fond Kabinet Maršala Jugoslavije, 836, 1-3-v/44, Urgent Ministarstvu inostranih poslova, 1. jul 1948. U toj noti se navodi da je „,vlada Jugoslavije u vezi sa sporazumima sa Vladom NRA imala sasvim protivne i osuđujuće namere postavljajući i izvršavajući ove odnose na kapitalističkim, eksploatatorskim i protivalbanskim temeljima“, da je ,jugoslovenska vlada sprovodila na brutalan način politiku dominacije“, i da je ,sprečila da se naša privreda razvija i napreduje na putu ka socijalizmu.“ Tada, Albanija nije otkazala jedino Ugovor o prijateljstvu i uzajamnoj pomoći, ,jer je on bio i jeste prema gledištu Vlade NRA važan akt koji konkretizuje želje oba naša naroda. Vlada NRA je mišljenja da taj ugovor ostaje i da se što više učvrsti i da posluži kao baza za ispravan razvitak odnosa između oba naša prijateljska naroda u budućnosti“. AJ, CK SKJ, 507/9, Komisija za međunarodne veze, 1/1-196, 1. jul 1948. Ugovor o prijateljstvu Jugoslavija je raskinula 12. novembra 1949. Dokumenti spoljne politike SFRJ, 1949, 296-303.

${ }^{74}$ DA MSP, PA, Albanija, 1948, f. 4, dos. 13, sign. 418273, Treće regionalno odeljenje - Ministarstvu inostranih poslova FNRJ, 6. jul 1948.

${ }^{75}$ AJ, 50-57-119, 6. jul 1948.

76 Александар Животић, „Немирна граница. Пограничне тензије између Југославије и Албаније 1948-1954“, Историјски записи, бр. 1-2, (2009), 109-110.

${ }^{77}$ DA MSP, PA, Albanija, 1948, f. 4, dos. 13, sign. 424523, Ministarstvo unutrašnjih poslova FNRJ - Ministarstvu inostranih poslova FNRJ, 16. septembar 1948.

78 AJ, CK SKJ, 507/9, Komisija za međunarodne veze, 1/ 2-111, Rezolucija 11. plenuma KP Albanije.

79 Tada je promenjen naziv partije u Partija rada, što je predložio Staljin prilikom susreta sa Enverom Hodžom. Kongres KPA je održao 23 sednice i celokupna dešavanja na ovom kongresu mogu se naći u dokumentu: DA MSP, PA, Albanija, 1948, f. 1, dos. 7, sign. 431587, Prvi kongres partije rada Albanije, 28. decembar 1947. 
novembra 1948, Enver Hodža je odredio politiku prema Jugoslaviji za sledećih pet godina. ${ }^{80}$ Prekidom jugoslovensko-albanskih odnosa 1948. učestali su incidenti na granici Jugoslavije i Albanije, ${ }^{81}$ a na jugoslovenske molbe i note da se stanje smiri albanska strana nije reagovala (od 2. jula 1948. do 10. jula 1950. Ministarstvo inostranih poslova i Poslanstvo u Tirani uputili su 25 protestnih nota). Albanske vojne jedinice su dislocirane duž granice sa Jugoslavijom, a regruti i rezervni sastav držani su u stalnoj pripravnosti. Zbog promene u albanskom stavu prema Jugoslaviji, jugoslovenska vlada je 4. juna 1950. obustavila rad svog Poslanstva u Tirani, a poslove sa albanskom vladom obavljala je preko svoje ambasade u Budimpešti. Albanija je rad svog Poslanstva u Beogradu obustavila 22. novembra iste godine. ${ }^{82}$

Nakon normalizacije odnosa SSSR-a i istočnoevropskih zemalja sa Jugoslavijom, koja je usledila posle Staljinove smrti $1953,{ }^{83}$ Jugoslavija i Albanija su 1954. ponovo otvorile svoje poslanstva u Tirani i Beogradu. ${ }^{84}$

${ }^{80}$ AJ, CK SKJ, 507/9, Komisija za međunarodne veze, 1/ 2-119, Prvi kongres Albanske partije rada.

${ }^{81}$ Миодраг Гаталовић, Косово и Метохија у државној политици Југославије 1958-1965 (Београд: Институт за савремену историју, 2016), 50; Димитрије Богдановић, Кюига о Косову (Београд: Књижевне новине, 1986), 303. U periodu 1948-1958. bilo je 12 ubistava i 22 ranjavanja jugoslovenskih graničara, 227 povreda teritorije FNRJ, 388 ostalih graničnih incidenata. Bela knjiga o neprijateljskoj politici Vlade Narodne Republike Albanije prema Federativnoj Narodnoj Republici Jugoslaviji (Beograd: Državni sekretarijat za inostrane poslove Federativne Narodne Republike Jugoslavije, 1961), 139; O kontrarevolucionarnoj i klevetničkoj kampanji protiv socijalističke Jugoslavije, knj. 2 (Beograd: Borba, 1950), 193-195.

82 Владимир Цветковић, „Дипломатске мисије ФНРЈ у Софији, Букурешту и Тирани 19531954: повратак амбасадора, услови рада и инциденти“, у: Југословенска дипломатија 19451961, ур. Слободан Селинић (Београд: Институт за новију историју Србије, 2012), 206.

83 Đ. Borozan, „Jugoslovensko-albanski odnosi u prvoj deceniji Hladnog rata“, 137. Više o normalizaciji odnosa Jugoslavije i Albanije i zemljama „narodne demokratije“ u susedstvu 1953-1958: Владимир Цветковић, Поглед иза гвоздене завесе: југословенска политика према земьама народне демократије у суседству 1953-1958 (Београд: Институт за новију историју Србије, 2013).

${ }^{84}$ М. Коматина, $н . \partial ., 95$. 


\section{REFERENCE}

- Adamović, Vladimir. „Enver Hodža: mehanizmi vlasti“. Ideje: jugoslovenski studentski časopis, br. 5-6, (1987), 162-171.

- Albania and Kosovo. Political and ethnic boundaries 1867-1946, editor Beytullah Destani. Slough: Archive Editions, 1999.

- Avramovski, Živko. „Italijanska ekonomska penetracija u Albaniji 1925. do 1939“. Istorija 20. veka, br. 5, (1963), 137-224.

- Avramovski, Živko. „Problem Albanije u jugoslovensko-italijanskom sporazumu od 25. marta 1937“. Historijski pregled, br. 1, (1963), 19-31.

- Balevski, Milčo. Albanija po Enver Hodža. Skopje: Makedonska kniga, 1987.

- Baruti, Vasfi. Enver Hoxha në optikë të re. Tiranë: Uegen, 2012.

- Bataković, Dušan. „Ahmed beg Zogu i Srbija“. U: Naučni skup Srbija 1916. Priredio Slavenko Terzić, 165-177. Beograd: Istorijski institut SANU, 1987.

- Bela knjiga o neprijateljskoj politici Vlade Narodne Republike Albanije prema Federativnoj Narodnoj Republici Jugoslaviji. Beograd: Državni sekretarijat za inostrane poslove Federativne Narodne Republike Jugoslavije, 1961.

- Bogdanović, Dimitrije. Knjiga o Kosovu. Beograd: Književne novine, 1986.

- Borozan, Đorđe. Velika Albanija: porijeklo - ideje - praksa. Beograd: Vojnoistorijski institut Vojske Jugoslavije, 1995.

- Borozan, Đorđe. „Jugoslovensko-albanski odnosi u prvoj deceniji Hladnog rata“. U: Velike sile i male države u Hladnom ratu 1945-1955, Slučaj Jugoslavije. Urednik Ljubodrag Dimić, 131-139. Beograd: Katedra za istoriju Jugoslavije - Filozofski fakultet u Beogradu, Arhiv Jugoslavije, 2005.

- Borozan, Đorđe. „Jugoslavija i Albanija u dvadesetom vijeku“. U: Jugoslovenska država 1918-1998, zbornik radova. Urednik Đorđe O. Piljević, 199211. Beograd: Kultura, 1999.

- Britanci o Kraljevini Jugoslaviji. Godišnji izveštaji Britanskog poslanstva u Beogradu 1921-1938, knj. 2. Priredio Živko Avramovski. Beograd: Arhiv Jugoslavije; Zagreb: Globus, 1986.

- Cvetković, Vladimir. „Diplomatske misije FNRJ u Sofiji, Bukureštu i Tirani 1953-1954: povratak ambasadora, uslovi rada i incidenti“. U: Jugoslovenska diplomatija 1945-1961, zbornik radova. Urednik Slobodan Selinić, 205-220. Beograd: Institut za noviju istoriju Srbije, 2012.

- Cvetković, Vladimir. Pogled iza gvozdene zavese: jugoslovenska politika prema zemljama narodne demokratije u susedstvu 1953-1958. Beograd: Institut za noviju istoriju Srbije, 2013.

- Dervishi, Kastriot. Kryeministrat dhe ministrat e shtetit shqiptar në 100 vjet. Tiranë: 55, 2012.

- Dervishi, Kastriot. Lëvizja Komuniste në vitet 1924-1944 dhe formimi $i$ PKSH-së. Tiranë: 55, 2016.

- Dimić, Ljubodrag i Miladin Milošević. „Međudržavni ugovori između Jugoslavije i Albanije 1918-1939“. Tokovi istorije, br. 1, (1990), 33-51. 
- Đaković, Spasoje. Fadilj Hodža i Enver Hodža. Beograd: Naučna knjiga, 1989.

- Elsie, Robert. A biographical dictionary of Albanian history. London... [etc.]: I. B. Tauris, 2013.

- Fevziu, Blendi. Enver Hoxha. Tiranë: UET Press, 2011.

- Fevziu, Blendi. Enver Hodža: prva biografija zasnovana na dokumenti od ličnata arhiva $i$ na ispovedite na onie što go poznavaa. Skopje: Fondacija Otvoreno opštestvo - Makedonija, 2014.

- Fischer, Bernd Jurgen. King Zog and the Struggle for Stability in Albania. Boulder: East European Monographs, 1984.

- Fowkes, Ben. Eastern Europe 1945-1969. From Stalinism to Stagnation. Harlow [etc.]: Longman, 2000.

- Gatalović, Miodrag. Kosovo i Metohija u državnoj politici Jugoslavije 19581965. Beograd: Institut za savremenu istoriju, 2016.

- Hoptner, Jakob. Jugoslavija u krizi 1934-1941. Rijeka: Otokar Keršovani, 1973.

- Hrabak, Bogumil. „Političko-bezbednosna situacija u Albaniji 1945-1947“. Istorija 20. veka, br. 1-2, (1990), 77-115.

- Hronologija revolucionarne delatnosti Josipa Broza Tita, priredili Branislav Ilić i Vojislav Ćirković. Beograd: Export-press, 1978.

- Hrvatski biografski leksikon, knjiga III. Zagreb: „Leksikografski zavod Miroslav Krleža“, 1993.

- Jugoslavija 1918-1988. Tematska zbirka dokumenata, priredili Branko Petranović i Momčilo Zečević. Beograd: Rad, 1988.

- Ko je ko u Jugoslaviji: jugoslovenski savremenici. Beograd: Hronometar, 1970.

- Komatina, Milorad. Enver Hodža i jugoslovensko-albanski odnosi. Beograd: Službeni list SRJ, 1995.

- Marović, Miodrag. Balkanski džoker: Albanija i Albanci: istorijska hronika nastajanja i razvoja albanskog pitanja. Bar: Kulturni centar, 1995.

- O kontrarevolucionarnoj i klevetničkoj kampanji protiv socijalističke Jugoslavije, knj. 2. Beograd: Borba, 1950.

- Pavlović, Blagoje K. Stradanje Srba 1389-2009. Beograd: B. K. Pavlović: DTA, 2010.

- Pearson, Owen. Albania and King Zog: independence, republic and monarchy 1908-1939. London; New York: Centre for Albanian Studies in association with IB Tauris Publishers, 2004.

- Pollo, Stefanaq. Historie de l'Albanie. Roanne: Editions Horvath, 1974.

- Prifti, Peter R. Socialist Albania since 1944. Domestic and Foreign Developments. Cambridge: MIT Press, 1978.

- Rafailović, Jelena. Razvoj industrije na Balkanu. Tekstilna industrija u Kraljevini Srba, Hrvata i Slovenaca i Bugarskoj 1919-1929. Beograd: Institut za noviju istoriju Srbije, 2018.

- Slavković Mirić, Božica. Političke, ekonomske i kulturne prilike na Kosovu i Metohiji 1929-1941. Beograd: Prosveta: Princip, 2018. 
- Tomes, Jason Hunter. King Zog, Self-Made Monarch of Albania. New York: New York University Press, 2003.

- Verli, Marenglen. Shqipëria dhe Kosova - historia e një aspirate (Albania and Kosovo - story of an aspiration), vol. I-II. Tirana: Botimpex, 2007.

- Vojna enciklopedija, knjiga 9, urednik Nikola Glavežić. Beograd: Redakcija Vojne enciklopedije, 1975.

- Zapisnici sa sednica Politbiroa CK KPJ (11. jun 1945-7. jul 1948), priredio Branko Petranović. Beograd: Arhiv Jugoslavije, Službeni list SRJ, 1995.

- Zlatar, Pero. Enver Hodža - politička biografija. Beograd: Rad, 1986.

- Životić, Aleksandar. „Jugoslavija i jačanje sovjetskog uticaja u Albaniji 1947-1948“. Tokovi istorije, br. 3, (2010), 94-116.

- Životić, Aleksandar. Jugoslovensko-sovjetske vojne suprotnosti (1947-1957). Iskušenja savezništva. Beograd: Arhipelag, Institut za noviju istoriju Srbije, 2015.

- Životić, Aleksandar. „Nemirna granica. Pogranične tenzije između Jugoslavije i Albanije 1948-1954“. Istorijski zapisi, br. 1-2, (2009), 108-127. 
BOŽICA SLAVKOVIĆ MIRIĆ, PhD, Research Associate

Institute for Recent History of Serbia

Belgrade, Republic of Serbia

bozica.slavkovic@gmail.com

\section{BORDER TRAFFIC OF YUGOSLAVIA AND ALBANIA \\ AND TWO-OWNER ESTATES 1945-1948}

Summary

As neighbors, Albania and Yugoslavia relied on each other economically. Before World War II, border traffic between Yugoslavia and Albania was governed by the provisions of the Treaty of Commerce and Navigation. After 1945, the two countries fostered economic cooperation, and the resolution of relations along the Albanian-Yugoslav border was of great importance. To that end, negotiations were conducted, resulting in the signing of the Agreement on Border Traffic between Yugoslavia and Albania. After the visit of Enver Hoxha to Yugoslavia, border cooperation gained more intimate forms; customs borders were abolished and currencies of both countries were equalized. The problem of landholdings by two owners (dvovlasnici) was being resolved by a commission, which was organized in February of 1947. The commission concluded that the problems emerged because the Albanian authorities had implemented the land reform incorrectly. A mixed Yugoslav-Albanian Commission was organized to solve this problem. The Commission decided that all expropriated land should be returned for cultivation; shepherds in Yugoslavia were able to drive their cattle out to pastures in Albania; issuing licenses for landholdings with two owners should be more efficient, and it was necessary to identify suitable sites for crossing the border. An open crisis in Yugoslav-Albanian relations began after Albania's acceptance of the Cominform, when the Yugoslav-Albanian border was closed and there were numerous incidents.

KEYWORDS: Yugoslavia, Albania, Landholdings with two Owners, Border Traffic, Post-World War II Period 